\title{
Prediction of cardiorespiratory fitness from self-reported data in elderly
}

\section{Predição da aptidão cardiorrespiratória através de dados auto-relatados em idosos}

\author{
Geraldo A Maranhao Neto ${ }^{1}$ \\ Aldair J Oliveirat, \\ Rodrigo Pedreiro \\ Silvio Marques Neto ${ }^{1,3}$ \\ Leonardo G Luz ${ }^{4}$ \\ Henrique C Silva ${ }^{3}$ \\ Paulo TV Farinatti ${ }^{1,5}$
}

Abstract - Cardiorespiratory fitness (CRF) is associated with several health outcomes. Some non-exercise equations are available for CRF estimation. However, little is known about the validation of these equations among elderly. The aim of this study was to exam the validity of non-exercise equations with self-reported information in elderly. Participants $(n=93)$ aged 60 to 91 years measured CRF using maximal cardiopulmonary exercise test. Five non-exercise equations were selected. Data included in the equations (age, sex, weight, height, body mass index, physical activity and smoking) were self-reported. Coefficient of determination $\left(\mathrm{R}^{2}\right)$ of linear regressions with laboratory-measured $\mathrm{VO}_{2 \text { peak }}$ ranged from 0.04 to 0.64 . The Bland-Altman plots showed higher agreement between achieved and predicted CRF obtained by Jackson and colleagues, and Wier and colleagues equations. On the other hand, the other equations showed lower agreement and overestimation. Our findings provide evidences that two non-exercise equations, previously developed, could be used on the prediction of CRF among elderly.

Key words: Physical fitness; Regression Analysis; Aged .

Resumo - A aptidão cardiorrespiratória (ACR) está associada a vários desfechos de saúde. Algumas equaçôes sem exercício estão disponíveis para estimar a ACR. No entanto, pouco se sabe sobre a validação dessas equações entre os idosos. Objetivo: $O$ estudo foi desenvolvido com o objetivo de examinar a validade de equaçôes sem exercício com informações auto-relatadas em idosos. Métodos: Os participantes $(n=93)$ com idades entre 60 e 91 anos foram submetidos ao teste de exercício cardiopulmonar máximo para avaliar a ACR. Cinco equaçôes sem exercício foram selecionadas. Os dados incluidos nas equaçóes (idade, sexo, peso, altura, indice de massa corporal, atividade física e tabagismo) foram auto-relatados. Resultados: O coeficiente de determinação $\left(R^{2}\right)$ das regressöes lineares com o $\mathrm{VO}_{2}$ pico, medido em laboratório, variou de 0,04 a 0,64. Os gráficos de Bland-Altman mostraram maior concordância entre a ACR obtida e prevista por Jackson e colaboradores, e equaçôes de Wier e colaboradores. Por outro lado, as demais equações mostraram menor concordância e superestimação. Conclusões: Nossos resultados fornecem evidências de que duas equações sem exercício, previamente desenvolvidas, poderiam ser usadas na estimação da ACR em idosos.

Palavras-chave: Aptidão física; Análise de Regressão; Idoso.

1 Universidade Salgado de Oliveira. Laboratório de Ciências da Atividade Física. Programa de Pós Graduação em Ciências da Atividade Física. Niterói, RJ. Brasil.

2 Universidade Federal Rural do Rio de Janeiro. Departamento de Educação Física e Desportos. Seropédica, RJ. Brasil.

3 Universidade do Grande Rio. Rio de Janeiro, RJ. Brasil.

4 Universidade Federal de Alagoas. Laboratório de Cineantropometria, Atividade Física e Promoção da Saúde. Maceió, AL. Brasil.

5 Universidade do Estado do Rio de Janeiro. Laboratório de Atividade Física e Promoção da Saúde. Rio de Janeiro, RJ. Brasil.

Received: 14 March 2017 Accepted: 30 September 2017

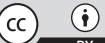

Licença Creative Commom 


\section{INTRODUCTION}

Cardiorespiratory fitness (CRF) has been linked to numerous health conditions, including coronary heart disease ${ }^{1}$, stroke ${ }^{2}$, high blood pressure ${ }^{3}$ and all-cause mortality ${ }^{4}$. In fact, low levels of CRF reduce the overall efficiency of the cardiovascular system. Additionally, $\mathrm{CRF}$ is directly associated with muscle strength ${ }^{5}$ and flexibility ${ }^{6}$ and inversely associated with age . $^{7}$

There are different strategies to evaluate the CRF. The most accurate one is to determinate objectively CRF using progressive tests of maximum effort with the direct oxygen consumption measured (VO2max). This form of measurement is considered the "gold standard". However, in large populations this method shall not be indicated due to the high costs for implementation and time spent on test. CRF can also be estimated by indirect tests that typically use physical exercise concomitantly with equations which estimate $\mathrm{CRF}$ based on information such as predicted maximum heart rate (e.g. 220 - age), age, sex. Despite the indirect tests having less accurate results than direct ones, they require a lower cost and logistic involved to their achievement. An interesting alternative to evaluate the CRF would be through prediction model without performing exercises. This method was developed with the application of multiple regression equations containing information on the weight, height, sex, age and lifestyle habits related to CRF. When compared to the maximal tests, the results are less accurate, however, when compared to submaximal tests presents similar estimate of power and greater applicability in more numerous sample groups ${ }^{8}$.

The assessment of the CRF is an important physiological indicator of the functional capacity among elderly ${ }^{9}$. However, the application of exercise tests in elderly may be limited due to orthopedic problems and a high prevalence of frailty in this population ${ }^{10}$. The use of non-exercise equation for $\mathrm{CRF}$ evaluation could be a reasonable alternative. In this context, identifying a simple, lower-cost and lower risk alternative assessment of CRF would be of considerable importance to evaluate elderly.

The non-exercise equations have been an important alternative to easily predict the CRF by means of regression-based equations that usually include variables of simple and quick assessment, such as anthropometric measures, demographic characteristics, and daily life habits ${ }^{11,12}$. In this sense, several authors ${ }^{13-16}$ have developed equations using only self-reported data which have the advantages of been practicality and a low-cost alternative. However, the validation attributes of these non-exercise equations were not further investigated among elderly. Therefore, the study was designed with the aim of examining the validity of self-reported nonexercise equations in elderly.

\section{METHODOLOGICAL PROCEDURES}

\section{Subjects}

All individuals admitted between March 2005 and April 2008 to be en- 
gaged in the project "Idosos em Movimento Mantendo a Autonomia" were included in the study. The sample was submitted to a medical-functional evaluation including maximal exercise cardiopulmonary test, a wide kinanthropometric evaluation and a clinical investigation, performed by specialized physicians before starting the exercise program. In addition, they also filled in the questionnaire about physical activity level. Individuals presenting one or more of the following conditions were excluded: a) stable or rest angina pectoris; b) paroxysmal or complex ventricular arrhythmias; c) acute myocarditis or pericarditis; d) atrioventricular block of high-grade and low ventricular rate; e) acute myocardial infarction within the previous two years; f) severe aortic stenosis; g) severe hypertension or reactive to exercise one; h) important injury on the left main coronary artery; i) history of pulmonary embolism, $\mathrm{j}$ ) any acute disease, $\mathrm{k}$ ) physical or emotional limitations, 1) drug intoxication; $\mathrm{m}$ ) inability to understand the proposed procedures and $\mathrm{n}$ ) orthopedic problems that incapacitate the individual to the participate or could be made worse by it. Thus, the study had the participation of 93 individuals (54 men and 39 women ranged 60 to 91 years old) that written informed consent was obtained from all participants, and the research protocols were approved by the Ethics Committee of Social Medicine Institute (CEP-IMS) from the Rio de Janeiro State University. The research was conducted in Rio de Janeiro State University.

\section{Procedures}

The physical activity level was assessed using a Brazilian Portuguese version of the Physical Activity Rating (PA-R). The PA-R is a progressive scale with scores from 0 to 10 in which must be signaled the most suitable option to the physical activity history in the last 30 days. Individuals with "zero score" were classified as "physically inactive"; those with 1 point as "slightly active"; those from 2 to 3 as "moderately active" and those with 4 points or more on the levels were moderate to high intensity. Detailed information about the procedure is available in a previous publication ${ }^{17}$.

Participants performed a maximal cardiopulmonary exercise test on a cycle ergometer, model Cateye EC-1600 (Cat Eye, Tokyo, Japan), using the ramp protocol. An initial load of 25-50 watts was increased continuously in increments of 5-15 watts/min until exhaustion. For the measurement and analysis of expired gases, we used a metabolic analyzer VO2000 (MedGraphics, United States) with the measurement being held in ten second intervals. For determining work rate (watts) based on the maximum capacity for work estimated, to obtain the maximum effort between 6 and 12 minutes, according to the recommendations of the American Heart Association. Continuous monitoring of ECG was performed (ECG) 12-lead (Micromed $^{\circledR}$, Brasilia, Brazil), with measurements of blood pressure at rest every minute test, performed with aneroid sphygmomanometer WelchAlln of Tycos ${ }^{\circledR}$ (Arden, USA). Subjects were verbally encouraged to exercise to volitional fatigue. Interruption criteria were established for the tests, according to the literature recommendations ${ }^{18}$. The test was interrupted by 
maximum voluntary exhaustion. There was no limit imposed on the value of heart rate (HR) to be achieved.

In order to assess the non-exercise equations which would be applied in the study, we used the literature search. In this sense, inclusion criteria were adopted for the selection, as follows: (1) included elderly in their sample, (2) validation of models through maximum effort tests with direct oxygen consumption measured ("Gold Standard"), (3) provided relevant information regarding the models adjustments (at least $\mathrm{R}$ square and standard error of estimate - SEE), (4) include variables not only for its statistical significance, but for its theoretical justification. This strategy was used in a previous study ${ }^{19}$. In addition, the models should include variables that could be self-reported by the respondent. The selected equations are shown in Table 1 along with their respective standard error of estimate (SEE), correlation and determination coefficients $\left(\mathrm{R}^{2}\right)$.

Table 1. Non-exercise Models Included in the present study.

\begin{tabular}{|c|c|c|c|c|c|c|c|}
\hline $\begin{array}{l}\text { Author } \\
\text { (year) }\end{array}$ & Sex & Age & $n$ & Equation & $r$ & $\operatorname{Adj}^{2}$ & $\begin{array}{l}\text { SEE (ml/ } \\
\mathrm{kg} / \mathrm{min})\end{array}$ \\
\hline \multirow{2}{*}{$\begin{array}{l}\text { Jackson } \\
\text { et al. }{ }^{14}\end{array}$} & $M$ & \multirow{2}{*}{$20-70$} & 1393 & \multirow{2}{*}{$\begin{array}{l}56.363+1.921(\mathrm{PA}-\mathrm{R})-0.381 \text { (age) }-0.754 \\
(\mathrm{BMI})+10.987(\text { sex } 0-1)\end{array}$} & \multirow{2}{*}{0.78} & \multirow{2}{*}{0.61} & \multirow{2}{*}{5.7} \\
\hline & $\mathrm{F}$ & & 150 & & & & \\
\hline \multirow{2}{*}{$\begin{array}{l}\text { Mattews } \\
\text { et al. }{ }^{15}\end{array}$} & $\mathrm{M}$ & \multirow{2}{*}{$20-79$} & 390 & \multirow{2}{*}{$\begin{array}{l}34.142+0.133 \text { (age) }-0.005(\text { age })^{2}+11.403 \\
(\text { sex } 0-1)+1.463(\mathrm{PA}-\mathrm{R})+9.170 \text { (height) }- \\
0.254 \text { (weight) }\end{array}$} & \multirow[b]{2}{*}{0.86} & \multirow[b]{2}{*}{0.74} & \multirow[b]{2}{*}{5.6} \\
\hline & & & & & & & \\
\hline \multirow{2}{*}{$\begin{array}{l}\text { Wier et } \\
\text { al. }^{16}\end{array}$} & $\mathrm{M}$ & $21-82$ & 2417 & \multirow{2}{*}{$\begin{array}{l}57.402-0.372(\text { age })+8.596(\text { sex 0-1) +1.396 } \\
(\text { PA-R 0-10) - } 0.683(\mathrm{BMI})\end{array}$} & \multirow{2}{*}{0.80} & \multirow{2}{*}{0.64} & \multirow{2}{*}{4.9} \\
\hline & $\mathrm{F}$ & $19-67$ & 384 & & & & \\
\hline \multirow{2}{*}{$\begin{array}{l}\text { Cáceres et } \\
\text { al. }{ }^{13}\end{array}$} & M & $18-65$ & 5136 & $\begin{array}{l}39.390-0.409 \text { (age) }-0.307 \text { (weight) }-4.437 \\
\text { (physical activity) } \\
+0.254 \text { (height) }-3.081 \text { (smoking) }\end{array}$ & 0.71 & 0.51 & 7.3 \\
\hline & $F$ & $18-65$ & 3157 & $\begin{array}{l}31.733-0.244 \text { (age) }-0.219 \text { (weight) }-3.598 \\
\text { (physical activity) } \\
+0.151 \text { (height) }-1.486 \text { (smoking) }\end{array}$ & 0.65 & 0.42 & 5.7 \\
\hline
\end{tabular}

r- multiple correlation coefficient; Adj-adjusted; $\mathrm{R}^{2}$ - Coefficient of determination; SEE-Standard Error of Estimate; M-male; F- female; sex: female=0 male=1;PA-R - Physical Activity Rating; physical activity: sedentary=0; active=1; BMI-Body Mass Index

\section{Statistics Analysis}

In order to investigate sex differences, the Student t-test and chi-square or Fisher's exact test were performed for count and categorical variables, respectively. The relationship between achieved CRF and predicted CRF was analyzed using linear regression, and the correlation coefficient, adjusted $\mathrm{R}^{2}$ and SEE were calculated and compared. The visual analysis was carried out using the Bland Altman plots to evaluate whether the estimated CRF varied according to the achieved CRF levels. To help this analysis, 95\% limits of agreement (95\%LoA) were established, calculated from the mean difference between the reported and the measured. The statistical significance for all analyses was accepted as $\mathrm{P}<0.05$ and if the $95 \%$ confidence interval (CI) does not include the zero value. All calculations were performed using the Stata version 12 software (Statacorp ${ }^{\mathrm{TM}}$, College Station, TX, USA). 


\section{RESULTS}

A summary of the descriptive statistics for all variables according to sex were included in Table 2. It is also provides results from the significance tests. In this line, significantly $(\mathrm{p}<0.05)$ differences were detected across sex in the following variables: height, weight, BMI, and VO2 max. More details can be seen in Table 2 .

Table 2. Physical and demographic characteristics of participants $(n=93)$.

\begin{tabular}{lccc}
\hline Characteristics & \multicolumn{2}{c}{ Mean \pm SD } & \\
\hline & $\begin{array}{c}\text { Male } \\
(\mathrm{n}=54)\end{array}$ & $\begin{array}{c}\text { Female } \\
(\mathrm{n}=39)\end{array}$ & $\mathrm{p}(95 \% \mathrm{Cl})$ \\
\hline Age (years) & $68.7 \pm 7$ & $68.6 \pm 6$ & $0.935(-2.99-2.75)$ \\
\hline Height $(\mathrm{cm})$ & $172.7 \pm 6$ & $157.1 \pm 6$ & $<0.001(-18.9--12.9)$ \\
\hline Body weight $(\mathrm{kg})$ & $85.3 \pm 11$ & $64.0 \pm 17$ & $<0.001(-27.5--15.2)$ \\
\hline BMI(kg/m²) & $28.6 \pm 5$ & $25.9 \pm 4$ & $0.007(-4.68-0.74)$ \\
\hline PA-R Score & $1.9 \pm 1.4$ & $1.5 \pm 1.6$ & $0.189(-1.03-0.21)$ \\
\hline Inactive/Slightly active (\%)* & 42.5 & 48.7 & $0.07(-0.136-0.256) \dagger$ \\
\hline Moderately/Highly active (\%) & 57.5 & 51.3 & \\
\hline Physically Active (\%) & 68.5 & 53.8 & $0.194(-0.049-0.347)$ \\
\hline HR max (bpm) & $138 \pm 27$ & $142 \pm 24$ & $0.458(-6.77-14.90)$ \\
\hline V02 max (ml/kg/min) & $21 \pm 8$ & $16 \pm 5$ & $<0.001(-7.72--2.07)$ \\
\hline Risk factors and clinical history (\%) & & & \\
\hline Hypertension & 35.2 & 43.6 & $0.412(-0.28-0.11)$ \\
\hline Beta-blockers use & 16.7 & 17.9 & $0.872(-0.208-0.184)$ \\
\hline Diabetes & 9.3 & 5.1 & $0.456(-0.154-0.238)$ \\
\hline Dyslipidemia & 22.2 & 17.9 & $0.614(-0.156-2.00)$ \\
\hline History of Miocardial Infarction & 3.7 & 0 & $0.508(-0.159-0.233)$ \\
\hline
\end{tabular}

*Generated from PA-R Score; BMI: body mass index; PA-R-Physical Activity Rating; HR max: maximum resting heart rate; SD: standard deviation; V02 max: maximal oxygen consumption; †difference between Inactive/Slightly active and Moderately/Highly active; $p$ : $p$-value; significant for $\mathrm{p}<0.05$; $\mathrm{Cl}$ : confidence interval.

The results of the simple linear regressions relating laboratory-measure VO2 MAX and VO2 max based on non-exercise equations are shown in Table 3. The model which used VO2 max estimated by Matthews et al. ${ }^{15}$ explained $64 \%$ of the variance in laboratory-measure VO2max. However, there was a $12 \%$ drop in the determination coefficient. On the other hand, the models developed by Jackson et al. ${ }^{14}$ and Wier et al. ${ }^{16}$ showed only a 3\% and $5 \%$ drop, respectively. The CRF estimated by Cáceres et al. ${ }^{13}$ equations explained only $17 \%$ for men and $4 \%$ for women.

The Bland-Altman plots (Figure 1) show a higher agreement between achieved and predicted CRF obtained by the Jackson et al. ${ }^{14}(\mathrm{a})$ and Wier et $\mathrm{al}^{16}$ (c) models. In fact, there were more points close to zero in Wier et al. ${ }^{16}(\mathrm{c})$. The Matthews et al. ${ }^{15}$ (b) plot shows that the majority of the samples were above the zero-axis, representing an overestimation. A low agreement is clearly observed in the Cáceres et al. ${ }^{13}$ plots ( $\mathrm{d}$ and e). 
Table 3. Coefficients of correlation and determination and standard error of estimate (SEE) from simple linear regressions between cardiopulmonary fitness estimated by equations (independent variable) and laboratory-measure $\mathrm{VO}_{2}$ max.

\begin{tabular}{lccc}
\hline Author (Year) & $r$ & Adj R & $\begin{array}{c}\text { SEE } \\
(\mathrm{ml} / \mathrm{kg} / \mathrm{min})\end{array}$ \\
\hline Jackson et al. $^{14}$ & 0.76 & 0.57 & 4.6 \\
Mathews et al. $^{15}$ & 0.79 & 0.64 & 4.4 \\
Wier et al. $^{16}$ & 0.77 & 0.58 & 4.6 \\
Cáceres et al. $^{13}$ Men & 0.43 & 0.17 & 7.8 \\
Cáceres et al. ${ }^{13}$ Women & 0.22 & 0.04 & 4.7 \\
\hline
\end{tabular}

r- correlation coefficient; Adj - adjusted; $\mathrm{R}^{2}$ - Coefficient of determination; SEE- standard error of estimate

(a)

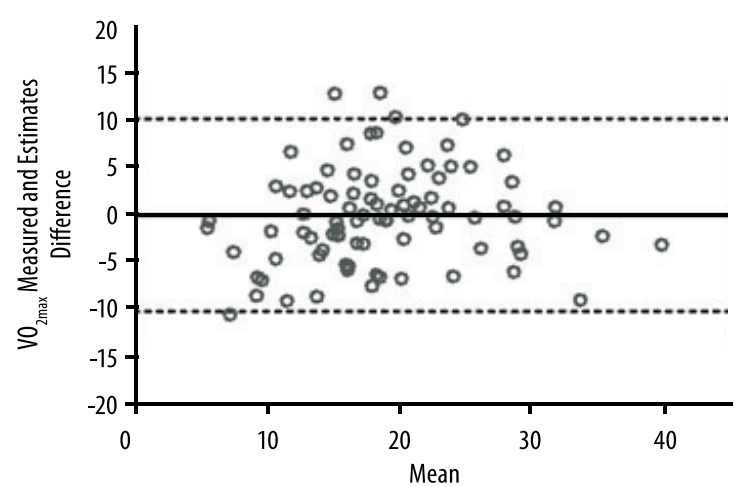

(c)

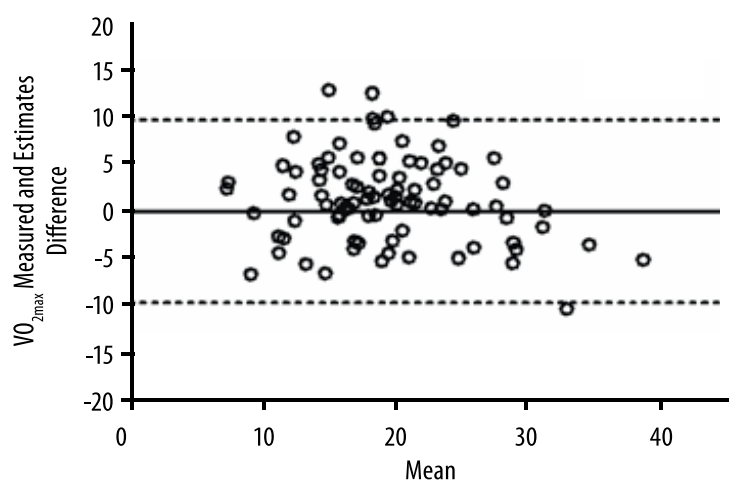

(b)

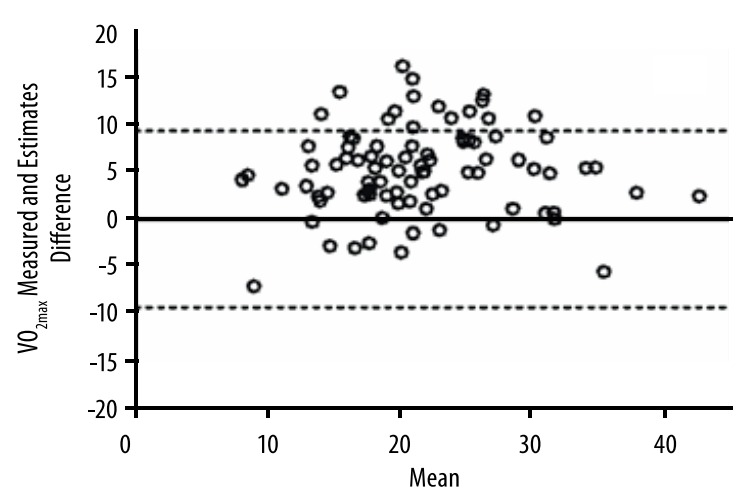

(d)

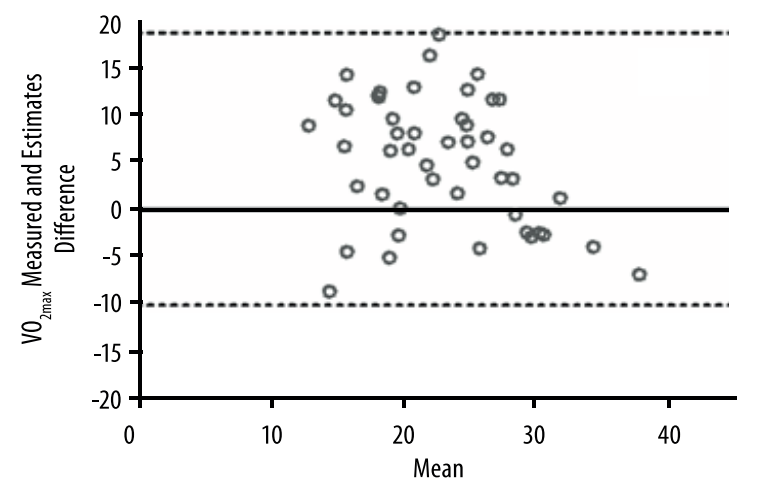

(e)

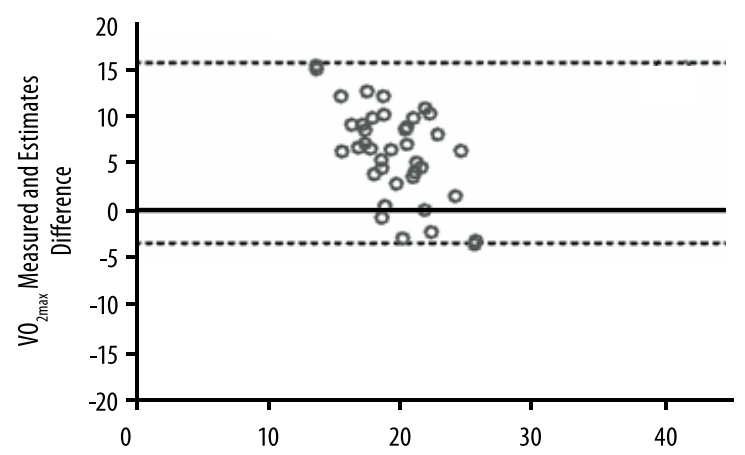

Figure 1. Bland Altman Plot between Achieved and Predicted ACR

Jackson et al.; (b) Matthews et al.; (c) Wier et al.; (d) Cacéres et al. Men; (e) Cáceres et al. Women; Dotted lines-95\% limits of agreement (LoA) 


\section{DISCUSSION}

The present study examined the validation of five non-exercise equations (e.g., Jackson et al. ${ }^{14}$, Wier et al. ${ }^{16}$ and Matthews et al. ${ }^{15}$, Cáceres et al. ${ }^{13}$ for men and women) on predicting CRF in Brazilian elderly. Our results showed reasonable indications of two equations: Jackson et al. ${ }^{14}$ and Wier et al. ${ }^{16}$ which could be helpful on the determination of CRF among elderly. On the other hand, the other three equations showed weaker validation performance, and consequently, and should be avoided in this group. In fact, Jackson et al. ${ }^{14}$ and Wier et al. ${ }^{16}$ had alreadly suggested that their equation could be more accurate for low fit subjects and people older than 50 years.

This study is the first to assess the validity of only self-reported non-exercise models in elderly. Mailey et al. ${ }^{20}$ tested the validity of the model proposed by Jurca et al. ${ }^{21}$ in an elderly sample (60-80 years). The model included the variables sex, age, $\mathrm{BMI}$, self-reported physical activity and resting heart rate $\left(\mathrm{R}^{2}\right.$ adjusted $\left.=0.51\right)$. Maranhão Neto et al. ${ }^{22}$ developed a model in a sample of 60-91 year, including the variables age, self-reported fitness and relative handgrip strength $\left(\mathrm{R}^{2}\right.$ adjusted $\left.=0.79\right)$. Variables such as resting heart rate and handgrip strength demand appropriate equipment and preparation, which limit the applicability of the models in population-based studies. Specifically, the heart rate responses could be affected by hypertensive medications and the handgrip test demand "motivation" from the subjects.

Our predictive values were slightly lower than the laboratory-measured $\mathrm{CRF}$ for most equations. Some explanations for these findings could be postulated. First, our sample was smaller than the ones in which the original equations were developed. Second, given that the equations were validated for a large age spectrum, it is plausible to consider that the precision of the estimates may not be identical in different age groups.

Taking into account the Bland-Altman plots, Jackson et $a .^{14}$ and Wier et al. ${ }^{16}$ equations had most of the points around zero highlighting a reasonable validation without bias. Both equations used easily self-report information (e.g., age, sex, weight, height and physical activity) and could be used in a population approach. On the other hand, the Bland-Altman plots of the other equations showed overestimation bias. These findings reinforce the importance of comparing equations, even though they use similar variables, aiming to access accurately CRF.

Although the equation developed by Matthews et al. ${ }^{15}$ explained 64\% of the laboratory-measure VO2 MAX variability, Bland-Altman plots revealed an overestimation, and consequently, the lower accuracy of this equation on estimate $\mathrm{VO} 2 \mathrm{MAX}$ in this group.

Through this research we found that many studies have been performed in order to estimate CRF without exercise for the general population. The main advantages found in this alternative are the lowest cost, the easier applicability and the speed of data acquisition, mainly in large populations ${ }^{19}$.

Some limitations of the study should be noted. Although the predicted values were close to that obtained from original equations, they were sys- 
tematically lower. All the original equations were validated against $\mathrm{VO}_{2}$ max obtained from maximal treadmill tests treadmill tests which are known to engage larger muscle mass and therefore elicit higher $\mathrm{VO}_{2}$ values ${ }^{23}$. The adoption of a cycloergometer maximal exercise testing protocol to assess the CRF is justified, mainly for safety reasons ${ }^{24,25}$.

Further, the findings of the study should be observed carefully due to the specific sample. The subjects were interested in engaging in project which involves physical activities and may present higher values of CRF compared with the general population. In this sense, it is not possible to state that the performance of these equations would be the same in other populations.

The use of non-exercise equations in elderly has two major justifications: (1) the physical health problems which may limit the participation in exercise tests ${ }^{26}$; (2) even in people without physical impairments, the exercise tests could not be feasible due to high-cost, especially in low- and middle-income countries.

\section{CONCLUSION}

This research provides evidence to support the use of a low-cost procedure of estimating CRF based on two equations previously developed (e. g. Jackson et al. $(1990)^{14}$ and Wier et al.(2006) $\left.{ }^{16}\right)$. The prediction does not involve any exercise testing, it provides reasonable estimates of CRF, and could be useful in research settings. Future studies should address whether non-exercise equations based on self-reported data could be used to follow changes in CRF of elderly.

\section{Acknowledgments}

The authors report no declarations of interest. This study was partially supported by grants from the Brazilian Council for the Technological and Research Development (CNPq), National Council for the Improvement of Higher Education (CAPES) and Carlos Chagas Foundation for the Research Support in the State of Rio de Janeiro (FAPERJ) no. E-26/203.237/2016.

\section{REFERENCES}

1. Pacheco MM, Teixeira LA, Franchini E, Takito MY. Functional vs. Strength training in adults: specific needs define the best intervention. Int J Sports Phys Ther 2013;8(1):34-43.

2. Cadore EL, Casas-Herrero A, Zambom-Ferraresi F, Idoate F, Millor N, Gomez $\mathrm{M}$, et al. Multicomponent exercises including muscle power training enhance muscle mass, power output, and functional outcomes in institutionalized frail nonagenarians. Age 2014;36(2):773-85.

3. Milton D, Porcari JP, Foster C, Gibson M, Udermann B. The effect of functional exercise training on functional fitness levels of older adults. Gund Lutheran Med J 2008;5(1):4-8.

4. Pinto RS, Correa CS, Radaelli R, Cadore EL, Brown LE, Bottaro M. Shortterm strength training improves muscle quality and functional capacity of elderly women. Age 2014;36(1):365-72. 
5. Liu CJ, Latham NK. Progressive resistance strength training for improving physical function in older adults. Cochrane Database Syst Rev 2009(3):Cd002759.

6. Beijersbergen CM, Granacher U, Vandervoort AA, DeVita P, Hortobagyi T. The biomechanical mechanism of how strength and power training improves walking speed in old adults remains unknown. Ageing Res Rev 2013;12(2):618-27.

7. de Vreede PL, Samson MM, van Meeteren NL, van der Bom JG, Duursma SA, Verhaar HJ. Functional tasks exercise versus resistance exercise to improve daily function in older women: a feasibility study. Arch Phys Med Rehabil 2004;85(12):1952-61.

8. Minick KI, Kiesel KB, Burton L, Taylor A, Plisky P, Butler RJ. Interrater reliability of the functional movement screen. J Strength Cond Res 2010;24(2):479-86.

9. Da-Silva Grigoletto ME, Brito CJ, Heredia JR. Functional training: functional for what and for whom? Rev Bras Cineantropom Desempenho Hum 2014;16(6):714-9.

10. Reid KF, Fielding RA. Skeletal muscle power: a critical determinant of physical functioning in older adults. Exerc Sport Sci Rev 2012;40(1):4-12.

11. Sayers SP, Guralnik JM, Thombs LA, Fielding RA. Effect of leg muscle contraction velocity on functional performance in older men and women. J Am Geriatr Soc 2005;53(3):467-71.

12. Thomas JR, Nelson JK, Silverman SJ. Métodos de pesquisa em atividade física, $5^{\text {a }}$ Ed. Porto Alegre: ArtMed, 2007.

13. Da-Silva Grigoletto ME, Viana-Montaner B, Heredia J, Mata Ordóñez F, Peña G, Brito C, et al. Validación de la escala de valoración subjetiva del esfuerzo OMNIGSE para el control de la intensidad global en sesiones de objetivos múltiples en personas mayores. Kronos 2013;12(1): 32-40.

14. Ribeiro AC, Oliveira KES, Rodrigues ML, Costa TH, Schmitz BA. Validação de um questionário de freqüência de consumo alimentar para população adulta. Rev Nutr 2006;19(5): 553-62.

15. Folstein MF, Folstein SE, McHugh PR. "Mini-mental state". A practical method for grading the cognitive state of patients for the clinician. J Psychiatr Res 1975;12(3):189-98.

16. Fleck MP, Louzada S, Xavier M, Chachamovich E, Vieira G, Santos L, et al. Aplicação da versão em português do instrumento abreviado de avaliação da qualidade de vida" WHOQOL-bref". Rev Saude Publica 2000;34(2):178-83.

17. Cook G, Burton L, Hoogenboom BJ, Voight M. Functional movement screening: the use of fundamental movements as an assessment of function - part 1. Int J Sports Phys Ther 2006;9(3):396-409.

18. Cook G, Burton L, Hoogenboom BJ, Voight M. Functional movement screening: the use of fundamental movements as an assessment of function-part 2. Int J Sports Phys Ther 2014;9(4):549-63.

19. Cohen J. Things I have learned (so far). Am psychol 1990;45(12):1304.

20. Krebs DE, Scarborough DM, McGibbon CA. Functional vs. strength training in disabled elderly outpatients. Am J Phys Med Rehabil 2007;86(2):93-103.

21. Bassey EJ, Fiatarone MA, O’Neill EF, Kelly M, Evans WJ, Lipsitz LA. Leg extensor power and functional performance in very old men and women. Clin Sci 1992;82(3):321-7.

22. Byrne C, Faure C, Keene DJ, Lamb SE. Ageing, Muscle Power and Physical Function: A Systematic Review and Implications for Pragmatic Training Interventions. Sports Med 2016;46(9):1311-32.

23. Pucci GCMF, Rech CR, Fermino RC, Reis RS. Associação entre atividade física e qualidade de vida em adultos. Rev Saude Publica 2012;46(1):166-79.

24. De Oliveira Leal SM, da Silva Borges EG, Fonseca MA, Junior EDA, Cader S, Dantas EHM. Efeitos do treinamento funcional na autonomia funcional, equilíbrio e qualidade de vida de idosas. Rev Bras Cienc Mov 2010;17(3):61-9.

25. Whitehurst MA, Johnson BL, Parker CM, Brown LE, Ford AM. The benefits of a functional exercise circuit for older adults. J Strength Cond Res 2005;19(3):647-51.

26. Karóczi CK, Mèszáros L, Jakab Á, Korpos Á, Kovács É, Gondos T. The effects of functional balance training on balance, functional mobility, muscle strength, aerobic endurance and quality of life among community-living elderly people: a controlled pilot study. New Med 2014; 18(1): 33-8.

\section{CORRESPONDING AUTHOR}

Geraldo de Albuquerque Maranhão Neto

Universidade Salgado de Oliveira Pós Graduação em Ciências da Atividade Física

Rua Marechal Deodoro, 263, Centro

- Niterói/RJ. Brasil

CEP: 24030-060

E-mail:maranhaoneto@gmail.com 